\title{
Vozes silenciosas, vozes silenciadas
}

\author{
Luiz Francisco Rebello
}

Uma tradução literal do tema deste congresso - Silent Voices, "vozes silenciosas" - poderia levar a supor-se que nele iria abordar-se a função do duplo ponto de vista sintáctico e semiótico, do silêncio como elemento estrutural do discurso dramático. E logo ocorreriam os nomes de Tchekov e Maeterlinck ou, mais próximos de nós, Beckett,

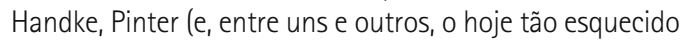
Jean-Jacques Bernard), em cujas peças o diálogo se constitui entre o que se diz e o que não é dito, e o silêncio disputa à palavra o lugar que uma concepção textocêntrica do teatro persiste em atribuir-Ihe.

Mas não é disso que se trata. Do que irá falar-se não é da palavra inarticulada, inexpressa, subjacente ao diálogo verbal, mas da palavra interdita, recusada, proibida de dizer-se. De vozes silenciosas, sim, mas porque foram "silenciadas". Da censura, portanto. Com efeito, a censura, qualquer que seja a sua natureza, o fim que se proponha atingir, é o "absoluto" do silêncio, uma pré-figuração da morte. Não terá sido por acaso que, em 1965, numa das fases mais agressivas da censura teatral, centena e meia de autores, actores, encenadores, críticos e técnicos de teatro subscreveram um protesto contra "as restrições que pesam sobre o teatro português e 0 estão condenando a um silêncio que se assemelha, cada vez mais, ao da morte". Não se enganavam: em 1973, não pôde subir à cena nenhuma peça nova de autoria portuguesa, e a pouco mais de dois meses do triunfo da revolução democrática era proibida a representação da Barca do Inferno, de Gil Vicente.

A extinção das comissões de censura, uma das primeiras medidas logo então tomadas, tornou possivel uma extraordinária revivescência da actividade teatral, paralisada ou, quando menos, "fiscalizada e reprimida" desde uma lei de Maio de 1927 em que estas palavras definiam, expressamente, as atribuições do aparelho censório. $E_{1}$ ao longo de quase meio século, os métodos de aplicação prática desse desígnio foram continuamente aperfeiçoadas. De início circunscrita ao texto da peça, a acção dos censores estendeu-se depois ao espectáculo, e até para além deste, pois acontecia também que uma peça cujo texto e cuja representação haviam sido autorizados viesse posteriormente a ser proibida. Aliás, remontava às origens da nacionalidade esta interferência castradora mas não havia já Platão defendido, no LivroX da República, a censura prévia e a expulsão da cidade dos poetas trágicos e cómicos, aqueles por excitarem as paixões, estes pelos excessos satíricos? Quatro séculos antes de Cristo, o filósofo grego acusava o teatro de corromper os costumes. Mas ainda no último quartel do século XIX, em Portugal, um sacerdote, o padre Sena Freitas, homem de cultura e saber aliás, considerava o teatro "uma das armas mais traiçoeiras com que os homens do mal buscam actualmente laquear e exterminar as crenças e os sentimentos católicos"!

Assim, por razões de salubridade moral, o teatro viase constrangido ao silêncio, o mesmo é dizer que à "inexistência". A essas razões outras vieram, entretanto, somar-se, tanto de ordem pública como privada, como é hoje em dia o caso dos interesses económicos dos grandes grupos empresariais. Por um lado, o Estado, atento a que os seus fundamentos, as instituições sobre as quais a sua autoridade repousa e as leis que the garantem a manutenção da ordem estabelecida não sejam postos em causa, por outro os condicionamentos impostos pela submissão às leis do mercado que regem a sociedade de consumo cujo objectivo único é o lucro, implicando a
Luiz Francisco Rebello é dramaturgo, crítico, ensaista, tradutor e historiador do Teatro Português. Licenciado pela Faculdade de Direito da Universidade de Lisboa, especializouse em direito de autor e foi durante 30 anos (1973-2003)

Presidente da Sociedade Portuguesa de Autores. Foi cofundador, em 1946, do Teatro-Estúdio do Salitre, onde se estreou como autor em 1947, com o drama

O Mundo Começou às 5 e 47. A sua produção dramática foi recentemente editada em dois volumes Todo o Teatro 1 (1999) e 11 (2006) - pela Imprensa Nacional Casa da Moeda. 
Cartaz do Congresso da FIRT/IFTR, Silent Voices, Forbidden Lives: Censorship and Performance, Lisboa, 12-18 de Julho 2009, organização do Centro de Estudos de Teatro, ilustrações de Rui Francisco / o bando.

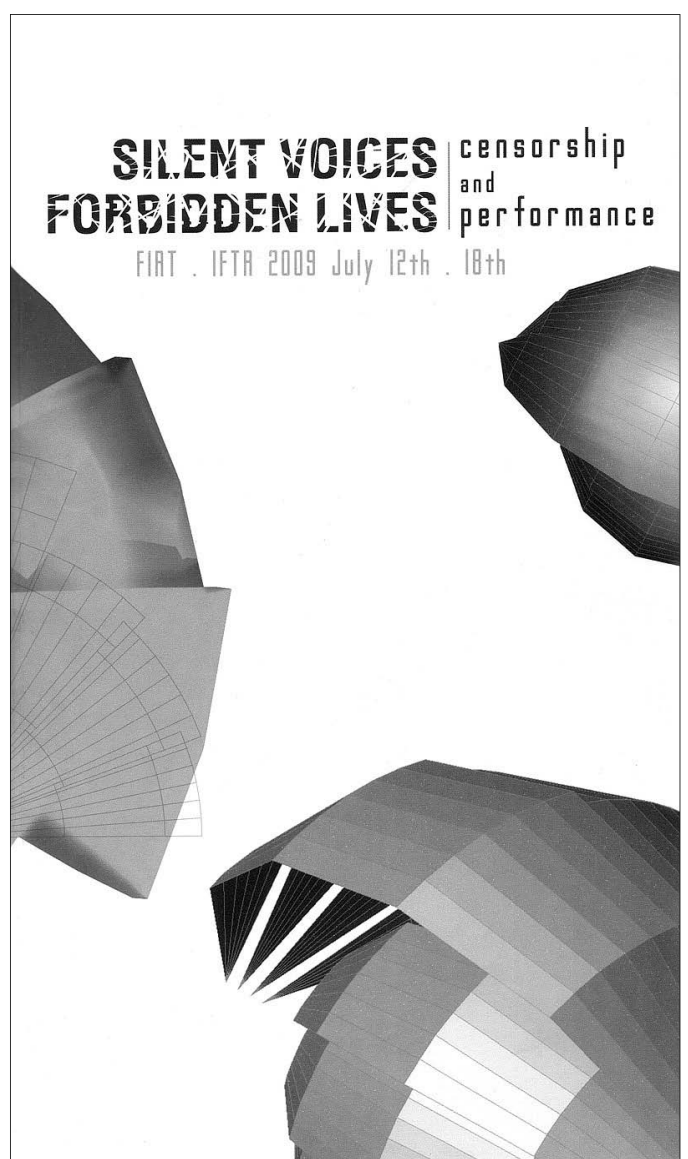

exclusão de toda e qualquer produção cultural de duvidosa rentabilidade, por não corresponder aos gestos da maioria, tais como estes foram padronizados, conjugam-se para o banimento de tudo o que não se identifique com a norma e é, portanto, encarado como uma heresia ou uma transgressão. E esta censura que "não diz o seu nome" (como a designa Michel Corvin) não é menos nociva do que a outra.

A presença da censura declarada ou encoberta, directa ou oblíqua, brutal ou subtil, macula as páginas da história do teatro português, desde as proibições eclesiásticas da Idade Média à sanha da Inquisição (que na Copilaçam de 1581 da obra vicentina apenas manteve cinco autos incólumes, e século e meio depois mandou queimar António José da Silva, que à condição de dramaturgo aliava o pecado de ser judeu), e, após intermitências várias, ensombrou os dois quartéis intermédios do século XX. A abertura dos arquivos da censura relativos a esse periodo permite-nos entrever os critérios que fundamentavam as proibições (que nunca eram comunicados) e estabelecer uma lista aproximada das peças condenadas, no todo ou em parte. Mas nunca poderemos contabilizar aquelas que não foram submetidas ao "exame prévio" (forma eufemista utilizada pelo marcelismo) por ser duvidosa, ou quase certa, a reprovação, e todas as que, por força dessa suspeita, não chegaram sequer a ser escritas. Essa é, sem dúvida, a mais odiosa de todas as formas de censura porque destrói a criação na sua própria fonte de origem.

A leitura dos relatórios é elucidativa acerca das motivações dos censores, que podem reduzir-se a duas linhas de força dominantes (com variações e ramificações diversas): a ideologia política e a moral católica. Proibiam- se peças que fizessem "a apologia das lutas de classes", fossem "de inspiração marxista", atacassem "os valores essenciais da civilização ocidental", acusadas de "fornecer combustivel para as fogueiras da contestação", ainda que por vezes algum censor menos inculto não deixasse de reconhecer o seu mérito literário e artístico - mas isso, a seu ver, tornava a peça "ainda mais perigosa". $E_{1}$ quando o sentido desta Ihe parecesse obscuro, reprovava-a "na dúvida e por prudência"... Outras vezes era "o agnosticismo e o cepticismo religioso bem conhecidos do seu autor" na ocorrência, Miguel Torga - que tornavam a obra suspeita. De resto, e de um modo geral, era preciso "ter muito cuidado com o teatro", recomendava-se numa circular de 1970 aos órgãos de imprensa.

Como noutra ocasião tive ensejo de dizer, "filtrada pela censura, a imagem que se transmitia era a dum pais em que não havia suicídios, abortos, greves, fome, epidemias, analfabetismo, homossexualidade, consumo de droga, em que as eleições não eram falsificadas, os tribunais não condenavam inocentes, a polícia não torturava nem matava, os soldados não desertavam nem morriam na guerra colonial porque não havia guerra nem colónias nem províncias ultramarinas, e até - supremo paradoxo - não havia censura". Nada disto existia, porque não se podia falar em nada disto, ocultado, anulado que era com o silêncio.

Graças à censura, Portugal não era um país, mas uma sucursal do paraíso. Aconteceu, porém, que num dia de Abril de 1974 os habitantes desse pais inexistente ousaram comer o fruto proibido da liberdade. E não foram eles, mas sim Deus quem foi expulso do paraíso.

E o pais voltou a existir. 